Kohl: a Journal for Body and Gender Research

Vol. 6, No. 1 (Summer 2020)

\title{
Health and Freedom: The Tense Interdependency of HIVIAIDS Interventions and LGBTIQ Activism in Kenya
}

Lucy W. Mung'ala and Anne de Jong

\begin{abstract}
:
In recent decades in Kenya, public health interventions to address the HIV vulnerability of sex workers and men who have sex with men have been accompanied by a rise in gender and sexual minority (hereby also interchangeably referred to as LGBTIQ) activist initiatives that frame access to healthcare, legal recognition, and social acceptance as a human right. Complementing long-term engagement and ethnographic research among sexual minorities in Kenya, in addition to fieldwork stints between 2016-2018, the authors analyzed online statements regarding priorities and strategies of LGBTIQ organizations (local and global) and legal case files. We examine one case in which transgender and intersex plaintiffs objected to the name and mission of an NGO working towards equality and full inclusion of sexual and gender minorities because it incorporated the words gay and lesbian while applying for its official registration and it would include trans and intersex in the organization's mission. As such, the politics of naming, identity, and representation are neither new nor exclusive to Kenyan LGBTIQ activism. This case and related files reflect the everyday interactions of groups with seemingly conflicting goals, showing them to be part of a rich, connected "niche activist" scene. Rather than take this as a rigid split between activist organizations, we argue that these tensions are historically rooted in - and form a microcosm of - the politics of the global NGOization of both healthcare access and human rights advocacy in Kenya.
\end{abstract}


The crux of the first and second interested parties' submissions is that there is a distinct difference between Lesbian, Gay, and Bisexual persons (LGB), and Transgender and Intersex persons (TI). According to the interested parties - Ms Audrey Mbugua Ithibu, a transgender woman, and Daniel Kandie, the father of an intersex child - gays and lesbians are cases of sexual orientation while transgender and intersex concerns are of a medical condition. They submit that other countries have made the differentiation, citing, as an illustration, the Gender Recognition Act of the United Kingdom which deals with issues of transgender and the Alteration of Gender Act of South Africa which differentiates issues of gender differentiation and sexual orientation. Their submission is that there is no community known as LGBTIQ as this implies that those who are transgender are also homosexual, which, is not the case. (Kenya Law Reports, ${ }^{1}$ petition 440 of 2013)

Homosexuality will eventually be accepted in Kenya though it would take years. ... I do not want to create the impression that if a Lesbian, Gay, Bisexual, Transgender or Queer case is brought to me, I will handle it as such, but Kenyans need to be heard. The Constitution provides for the protection of human rights. Let us understand them first.... But there should be no controversy surrounding intersex people since this is biological. It is not something they brought upon themselves. The courts have a responsibility to guide us through this. (Justice Wanjiru Karanja, Court of Appeal, October 5,2016$)^{2}$

The above excerpts concern a court case on the use of labels and representation in the procedure of registering a non-governmental organization (NGO) in Kenya. The court case consists of petitioner Eric Gitari, a gay activist, and two complainants of the already-registered organization Transgender Education and Advocacy (TEA). Gitari applied to officially register The National Gay and Lesbian Human Rights Commission (NGLHRC) as an NGO that addresses the violence and human rights abuses suffered by lesbian, gay, bisexual, transgender, intersex, and queer (LGBTIQ) people in Kenya. The complainants, Audrey Mbugua Mbugua and Daniel Kandie, both active within TEA, feared that an unfavorable verdict for Gitari could affect the operations of TEA as an already registered organization serving transgender and intersex people. The complainants thus objected to using the words "gay and lesbian" in direct connection with "transgender and intersex" because they believe that "sexual orientation is a choice whereas transgender and intersex people are faced with a medical condition." 3 The inclusion of lesbian, gay, and bisexual people within the same conceptual category as intersex and transgender people was considered a potential threat to an already favorable public perception and understanding of intersex and TEA's framing of transgender issues.

1 Petition No. 440 of 2013: http://kenyalaw.org/caselaw/cases/view/108412/. After five years of court process, in March of 2019 the Nairobi Court of Appeal ruled in favor of The National Gay and Lesbian Human Rights Commission to register as a nongovernmental organization: Civil Appeal No. 145 of 2015: http://kenyalaw.org/caselaw/cases/view/170057/

2 "Judge Says Kenyans Will Accept Homosexuals, But It Will Take Time." Nairobi News, October 6, 2016. https://nairobinews.nation.co.ke/news/judge-says-kenyans-will-accept-homosexuals-will-take-time

3 Petition No 440 of 2013: http://kenyalaw.org/caselaw/cases/view/108412/ 
This case exemplifies the tensions between gay, lesbian, and genderqueer/non-binary activists on the one hand, and transgender and intersex activists on the other. This rift parallels the strive for health access, visibility, and human rights among the LGBTQI community in Kenya. Rather than taking this as a rigid binary split within a local activist scene, we argue that these tensions are historically rooted in - and form a microcosm of - the politics of global NGOization of both healthcare access and human rights advocacy in Kenya. The aim of this paper is thus not to merely describe the different strategies and narrative of various local LGBTIQ activists and NGOs, but to critically connect these to the highly politicized and increasingly internationally funded context in which all Kenyan NGOs, activists, and grassroots initiatives must operate.

This article draws on the long-term engagement and research of the first author, Lucy Mung'ala, among sexual minorities in Kenya, including shorter fieldwork stints in 2016, 2017, and 2018 in Nairobi, Mombasa, and Kisumu as part of her doctoral research. As a practitioner-researcher she had access to activists and representatives of LGBTIQ organizations as well as transnational LGBTI rights NGO staff, primary donors, and gay and lesbian friends and acquaintances. All of the ethnographic data in this article are derived from ethnographic participant observation and semi-structured interviews with activists and representatives of LGBTIQ organizations. As a critical practitioner-anthropologist using multi-sited ethnography (Marcus, 1995), the first author analyzed individual and institutional levels and prioritized the voices of local interlocutors. This meant acknowledging the complex and often ambiguous relationships between LGBTIQ activists themselves and in relation to donors, which came to be the focus for the theoretical analysis presented in this article. To supplement the fieldwork-based data, both authors analyzed the online statements of local and global LGBTIQ organizations, regarding their priorities and strategies: legal documents, including court reports and rulings and case files, and activist public statements expressed on social media, such as Facebook posts where LGBTIQ content is disseminated and discussion forums and threads exist.

\section{Theoretical Framework: Local Activism and NGOization}

The value of evoking international human rights to secure formal protections for gender and sexual minorities lies in its ability to be used to make claims against governments for recognition and protection of their rights. Yet, such laws are often enacted through judicial or legislative mandates and remain unpopular with the public (Thoreson, 2008). In line with international trends and following the 2010 Kenyan constitution, LGBTIQ activism in Kenya has a robust rights-based framing mainly influenced by the western notions of LGBTIQ politics. However, as Tamale (2011) argues, "the identity politics that underpin these western notions of same-sex relations do not necessarily apply in African contexts" (p. 27).

The need for financial resources to address social justice and equality concerns for sexual minorities in Africa, and the availability of such resources from international NGOs, have shaped the ways that sexual minority organizations, activists, policymakers, and governments align themselves to global processes (Bayrer, 2012; Sanders et al., 2015; Currier, 2014). Financial dependency leads to power asymmetries because LGBTIQ organisations with a global mandate and funding tend to influence smaller groups, affecting how they frame issues in order to qualify for financial support (Osterbur \& Kiel, 2017; Kiel, 2011; Lerche, 2008). It also 
stimulates linking new "forms of life" around sexuality to Western "confessional technologies" deployed to fight AIDS stigma in the earlier days of the epidemic (Nguyen, 2013).

It is tempting to take a critical position towards the "NGOization" of LGBTIQ groups in Kenya - meaning the ascendancy of NGOs in the domain of gender and sexual rights, and the detachment of professionalized NGOs from grassroots actions and their assumed right to intervene. As Bornstein (2003) writes, "the transmittal of value and visions in development ... are an expression of the power of the aid industry worldwide" (p. 394; see also Elbers \& Arts, 2011). On the surface, locally driven activism and funder-driven interventions may seem at odds, but our research reveals a situation of interdependence. Going beyond the formal structures and professionalization, Alvares (2009) refers to "NGOization" as the "national and global neoliberalism's active promotion and official sanctioning of particular organizational forms and practices among feminist organizations and other sectors of civil society" (p. 176). As such, so-called Southern NGOs could bring to the table "local knowledge, grassroots linkages, implementation capacity and cultural understanding," but these do not stand firm against the financial power and positionality of Northern donors (Bornstein, 2003, p. 394). Moreover, relationships between Southern NGOs and local communities can be just as patronizing and biased as those between Northern donors and Southern NGOs (Mohan, 2002; Narayanaswamy, 2014).

While financial dependency of local activists' groups and international NGOs' far-reaching influence in both practice and discourse are acknowledged in this paper, we argue that the relationships between INGOs and LGBTIQ activists organisations is neither unidirectional nor solely negative (Townsend, Porter, \& Mawdsley, 2004; Sharma, 2008). As will be shown, for example, it was in the domain of healthcare NGOs - mainly those related to HIV - that spaces became fruitful for LGBTIQ activist mobilization. We thus posit that access to HIV interventions, whether within medical facilities or sites outside of them, had gone hand-in-hand with the struggle for human rights of LGBTIQ Kenyans. Approaching LGBTIQ grassroots activism, Kenyan NGOs, global health interventions, and global LGBT rights networks as a complex yet unified activism scene enables an analysis based more on lived experience (Sandfort \& Reddy, 2013; Thoreson \& Cook, 2011; Epprecht, 2012).

This article is structured as follows: we first describe in more detail the cases briefly introduced above in order to show the current political struggles over naming, representation, and identity among LGBTIQ activists in Kenya. While the divergent narratives and interests of different actors are explored, we simultaneously argue that the everyday interactions of seemingly conflicting groups, and identity politics are very much intertwined, creating a "niche activism" scene that is fractured yet connected. Second, we argue that these tensions are intimately connected to the evolution of national and international development initiatives and their primary focus on health. Because history is only linear in hindsight (Pappe, 2014), we portray the development of health, gender, and sexual minority activism and advocacy through ethnographic recollections of those involved. Third, we argue that the ambiguous interdependence of sexual health NGOs and grassroots LGBTIQ activists is central to today's strategies, alliances, and resources. In conclusion, we suggest that it is productive to approach ambiguous or even contradicting initiatives as interdependent actors within a 
historically developed and power-filled field, creating insights that are beneficial for local activists and practitioner-academics alike.

\section{Niche Activism and Judicialization}

In the court case introduced above, transgender and intersex activists Mbugua Ithibu and Kandie objected to the combined use of the phrases "gay and lesbian" and "transgender and intersex" in the name and mission of an NGO that was seeking official registration to complement the human rights efforts of existing LGBTIQ organizations. They argued that sexual orientation (what one does) should be distinct from gender identity (who one is). Furthermore, they feared that if the request for registration for this new NGO was denied, it might endanger the official status of their TEA organization. ${ }^{4}$ While it may be tempting to dismiss these concerns as reflecting an African conservativism that rejects Western LGBTIQ "progressive," rights-based politics (Nyeck \& Epprecht, 2013; Lennox \& Waites, 2013; Waites, 2009), we argue that it is first and foremost a deliberate counter-argument against prominent lesbian, gay, and bisexual (LGB) coalitions that represent LGBTIQ as a unified community. These dominant LGB groups and human rights-based organizations receive the lion's share of financial resources designated for gender or sexual rights activism, while transgender and intersex groups remain under-resourced. ${ }^{5}$ Because the majority of LGBTIQ funding in Kenya is connected to HIVIAIDS interventions, sexual minority women often get left out of such programs because they are considered to be at "low risk," thus becoming invisible even within the existing health policies that claim to include sexual and gender minorities (Wilson et al., 2019). Many transgender and intersex activists do not feel represented by the dominant gender and sexual minority activist initiatives because, beyond including "T" and "I" to their organization's names, they rarely address transgender and intersex concerns. Audrey, a transgender woman and activist, criticized the hegemonic power relations amongst LGBTIQ Kenyans, activists, and their organizations that tend to create a narrow understanding of acceptable genders and sexualities:

A large majority of people who use this term ["LGBTIQ"], including homosexual activists, do not understand what that "T" stands for or what the issues of transgender people are. Even worse, they pretend that they are addressing our issues - under a common umbrella of LGBTIQ, how? With the absence of trans people in these organizations or in leadership positions, they should just name their organizations for what they are. [Which is not a "Trans focused organisation"]. (Audrey, Nairobi, 2016)

The term "LGBTIQ" encompasses a diverse group of gender and sexual identities, and it is often assumed to be fully inclusive while downplaying tensions or less dominant groups. But there are also others, for

${ }^{4}$ TEA was formed in 2008 after years of being denied registration. In 2014, the High Court of Kenya ordered The National Council of NGOs to officially register TEA.

5 https://ajws-americanjewishwo.netdna-ssl.com/wp-content/uploads/2017/10/Trans-report.pdf and https://ajwsamericanjewishwo.netdna-ssl.com/wp-content/uploads/2017/10/Intersex-report.pdf 
example, women who have sex with women (WSW) or men who have sex with men (MSM), who may not identify as part of the LGBTIQ population or gay community (Boellstorff, 2011; Morgan \& Wieringa, 2005). Coined to describe behaviors rather than social or cultural identities, "MSM" is a medicalized term to describe an "at-risk group" following the emergence of HIVIAIDS, and the idea that it is not who you are, but it is what you do that defines you (Baral et al., 2007; Boellstorff, 2011).

Different preferences for terminology are not just semantics; they reflect different interests and strategies of various constituencies. We argue that, although commonly referred to as the "Kenyan LGBTIQ movement," the variety of local activists, NGOs, and grassroots initiatives can better be described as a "niche activism" scene (Levitsky, 2007, p. 272) that includes diverse groups of gender and sexual identities, each with distinct needs and advocacy strategies. Levitsky (2007) describes niche activism as the specialization of diverse actors and organizations, each with particular tactics to achieve distinct goals within a given context. In Kenya, the need for a range of facilities and organizations to address the variety of needs saw the rise of a fractured, yet united niche activism scene that was interdependently bounded together by donor-drive NGOization and processes of judicialization. NGOization in the context of Kenya reverses less to a donordriver adoption of global LGBTIQ jargon (Jad, 2003) but specifically to donor-driven professionalization and the encouragement to certain strategies (judicialization, media advocacy) that privileges some activists and marginalizes others.

While approaching this variety of actors - grassroots activists, local NGOs, global health organizations - as a single activist scene, we wish to still emphasize the real differences in interests and the struggles for limited resources. Instead of setting different groups aside and compare them, we argue that they are ambiguously interdependent. In the following we argue that ad hoc cooperation and interdependent alliances are 1) rooted in two decades of the NGOization of sexual health interventions and human rights organizations, and 2) form a microcosm of the broader power-filled legal and cultural environment in which they operate.

Because historical developments are only linear in hindsight, we can trace the development of both sexual health and human-rights oriented NGOs and grassroots initiatives through two significant events. The establishment of HIVIAIDS clinics, the so-called Tuesday clinic in this particular case, will show how such sexual health-focused spaces unintendedly served as sites for LGBTIQ mobilization. Actions during the 2007 World Social Forum, held in Nairobi, marked a shift towards visibility and freedom-oriented activism, an increase in human rights discourse among NGOs and donors, as well as a local backlash against "coming out."

\section{The Tuesday Clinic: HIVIAIDs Institutions as Sites for LGBTIQ Mobilization}

Almost fifteen years ago, Mung'ala became part of a group that set up one of the very first MSM clinics in Kenya, famously known as "the Tuesday clinic." At the time, Mung'ala had come to know of friends and acquaintances struggling to access non-stigmatizing sexual health and HIV services. Hosted by Liverpool Voluntary Care and Treatment (LVCT), the clinic was set up after numerous complaints about the lack of 
LGBT- and male sex worker-friendly sexual and reproductive health information and services, such as HIV testing and counseling. Her diary notes from that period read:

A friend shared his experience of visiting an STI clinic because he suffered from anal warts. Being an openly gay man and a nurse himself, he was keen to explain his symptoms in detail. To his dismay, the health-care provider was not interested and interjected him [sic] halfway through: "Ok, I get it. I do not need to hear details of how you contracted it; after all, the medicine I will offer you today treats all forms of STIs - it does not matter where they are!" After filling in a data collection questionnaire and only 15 minutes into his appointment, he received his medication without any physical examination. (Diary Excerpts, November 2005).

Shortly after, the Tuesday clinic opened its doors. Two medical doctors, a nurse, and two counselors staffed the clinic and ran it on a volunteer basis, in addition to their regular day jobs. Through their social contacts, the team had access to members of the gay community in Nairobi and their networks, which included male sex workers, bisexual women, and middle-class Kenyans and expatriates who self-identified as gay or lesbians. The Tuesday clinic was located in a residential housing unit in a middle-class neighborhood to ensure privacy and discretion. Services were offered between $6-8 \mathrm{pm}$ to serve the target communities. Accessing services between 6-8pm was considered a way to prevent interference with the client's livelihoods. For example, sex workers were served on their way to work (most were street corner sex workers at the intersection of Hurlingham and Lavington area). LVCT offices also provided a "chill-out" space where sex workers would get their make-up done and have a change of clothes, before heading to the streets or the nearby bars. Occasionally, tea and snacks would be served during the post-test support group meetings.

Out of these occasional tea-and-snacks gatherings grew a space for active mobilization. The Tuesday clinic became a crucial space for building activist networks where participants could get acquainted with Western gender and sexual identity terminology and the everyday realities of LGBTIQ organizing (Currie, 2012; Currie \& McKay, 2018; Lorway et al, 2014). The early members of the MSM support groups became politically active, and many are currently in leadership positions of LGBTIQ or sex worker organizations. The MSM support group also provided space for thinking about the relationship between social well-being and health, both mental and physical. It is in this space that activists consciously reconceptualized the relationship between health initiatives - shifting from what was considered an exclusive public health approach to a human-rights activist approach - to promote LGBTIQ inclusion in initiatives for health, legal recognition, and decriminalization. Till then, sexual minorities groups had adopted a public health approach to deliver targeted HIV programs to MSM, in order to avoid social and political antagonism; in some cases, this meant dismissing the call for equal rights of gender and sexual minorities and rejecting the visibility of LGBTIQ persons.

Demanding social justice, acceptance, and recognition have become core to the understanding of citizenship (Tamale, 2011; Currier, 2014). In Kenya, the existence of social and political institutions related to HIV prevention and treatment has made it possible to "intervene" and respond publicly to the needs of sexual minorities despite the antagonistic sociopolitical climate when discussing their rights and even their existence (NASCOP, 2012; KHRC, 2011; Giebel, 2012; Moyer \& Igonya, 2018). While facilitating and representing 
LGBTIQ networks was not an initial goal of LVCT, this HIVIAIDs intervention grew from only medical services focused on behavioral change and biomedical treatment to include MSM support groups, a space where a politically active LGBTIQ front developed. The first support group had about 15 members, mostly male sex workers and a few middle-class gay men, and this bi-monthly gathering grew in numbers as word spread.

In an interview, Jerry, a former MSM peer educator, recalled that over time members of the support group became less engaged in discussions of their HIV diagnosis and HIV prevention. Instead, they wanted to spend some of the Sunday afternoons at Arboretum Park. Picnics and queer parties became part of the support group's activities. For some group members, receiving an HIV diagnosis was enough reason to participate in the support group, while for others it was about celebrating life and who they were.

In the years that followed, LVCT went on to become the fiscal sponsor of the Gay and Lesbian Coalition in Kenya (GALCK) and was also tasked with helping to build the capacity of nascent LGBT groups. However, it's worth to note that LVCT management was hesitant in the beginning and insisted that a clear boundary should be made between public health and human rights advocacy. Mung'ala recalls a heated debate in one of the meetings, where sexual minorities through GALCK's leadership declared: "It is time for the LGBTIQ community to come out." A representative of GALCK explained that LGBTIQ Kenyans needed to be visible not only to the National AIDS Commission, which had previously referred to them as attention seekers, but also to the general public. Passionately he pleaded that asserting their rights to self-determination, dignity, and respect should be at the forefront of their struggle. With this statement, the group leader appealed to and reflected on the everyday experience of many LGBTIQ Kenyans, as they faced issues such as criminalization, stigmatization, and isolation well beyond the notions of access to healthcare.

Kenya is experiencing the re-establishment of clinics that are positioned as "one-stop shops," run by and for the community. For example, led by sex workers and MSM, Health Options for Young Men on HIV/AIDS/STI (HOYMAS) ${ }^{6}$ and Ishtar MSM ${ }^{7}$ have both established community-based clinics that provide a wide range of services from HIV testing, treatment, and referrals, to peer group support, nutritional aid, and social and legal services. From these early 2000s HIV intervention sites, support groups, and the sexuality conference convened by Urgent Action Fund-Africa, new LGBT organizations, including Gay and Lesbian Coalition of Kenya (GALCK), Gay Kenya Trust (GKT), and Minority Women in Action (MWA) sprang by 2006. From 2007 onward, these groups started registering as community-based organizations with the Ministry of Social Services, and later with the Kenyan NGO coordination board. It was not until 2009, however, that the Kenyan government recognized and included the category of MSM within its HIV prevention care and treatment programs. For the first time, in 2008/2009, members of the LGBT community were invited to participate in the development of the Kenya AIDS Strategic Plan of 2009-2014. This was to be the first government policy document that defined sexual minorities, MSM, and sex workers as a category of people particularly vulnerable to HIV infection and frequently lacking in adequate access to services (Sanders et al., 2015).

${ }^{6}$ https://www.galck.org/hoymas/

7 http://www.ishtarmsm.org/ 
HIVIAIDs initiatives initially focused mainly on healthcare organizations to avoid real or perceived local cultural upheaval (Teunis, 2001; Giebel, 2012; KHRC, 2011). The example of the Tuesday clinic also shows that these initiatives slowly but steadily grew into safe spaces and sites for LGBTIQ mobilization. The relocation of clinics away from hospitals to community based "standalone" sites simultaneously disconnected LGBTIQ activism and in particular with MSM healthcare from the "main" healthcare facilities and created an active space for $L G B T I Q$ rights mobilization.

There is growing recognition that support groups, especially for people living with HIV, impart members with a sense of responsibility towards self-care, with heightened self-esteem, as well as improved outcomes in health, and social and economic impacts (Nguyen et al., 2009; Heyer et al., 2010; Igonya, 2017). The development of the Tuesday clinic thus signals a broader move from primary healthcare oriented services toward a human rights framework, including the adoption of Western jargon (particularly, adding "Ql" to "LGBT") and an emphasis on visibility. It is tempting to portray this as a linear shift from one discourse (health) to another (human rights). However, a closer look at "visibility" as the core of the discrepancy between the different emphases and practices demonstrates that this can better be understood as an ambiguous interdependence.

\section{"We're Here! We're Queer!": Becoming More Visible}

The 2006 World AIDS Day march provided for a memorable moment for sexual minorities in Kenya because the protest was taken as an opportunity to express solidarity with related movements, such as those led by people living with HIV. It was also an opportunity for MSM and sex workers to be visible, as a group that is statistically characterized as a "most-at-risk population" (NASCOP, 2009). Having participated in some of the planning sessions, Mung'ala recalls the excitement, and the anxiety, when LGBTIQ activists painted banners with messages such as "All humans are equal" and "Health for all." For many, this was the first time they came out as members and supporters of the LGBTIQ community. The freshly established GALCK later described this event as the "coming-out" of queers in Kenya; the march, quite literally, put a face to the Kenyan queer community.

A year later, the World Social Forum 2007 in Nairobi provided another opportunity for the newly formed coalition of sexual minorities. ${ }^{8}$ The forum is understood as the gathering of an anti-globalization movement consisting of civil society organizations that challenge the capitalist neoliberalism of the World Economic Forum. In general, the forum aims to transform economic systems but the 2007 gathering, the first to be held on the African continent, primarily provided a platform for LGBTIQ Kenyans to be visible and claim their struggle in the context of human rights. For the gender and sexual minorities represented there, both from Kenya and many from other African countries, the platform offered an opportunity to share advocacy tactics

8 For a description of the World Social Forum and how it has evolved over the years, see: https://wsf2018.org/en/english-world-social-forum-2018/ 
and form transnational solidarities. Springing from the Aids day march, their presence at the forum sent a powerful message locally and abroad: "We are here, and we are queer." ${ }^{9}$

One of the preparatory meetings was organized through GALCK and co-facilitated by the then-coordinator of the MSM program at LVCT and a staff member of Norwegian Queer Solidarity, one of the early funders of GALCK through the Norwegian Agency for Development Cooperation. The idea was to host a safe space at the forum where open dialogue would take place between LGBTIQ activists and the Kenyan public and other conference participants. While this was seen as a risk, the LGBTIQ participants in the planning meeting decided that it would be worth it, and so the "Q-spot" safe space became a reality. In addition to open dialogue, the $Q$-spot functioned as an educational and informative space, with cultural performances, film screenings, and HIV information and testing services.

The Q-spot tent attracted much curiosity and was reported sensationally across the Kenyan media (ILGA, 2007). While this event had given the community the visibility they desired, safety and security became a concern. Some of the activists' names and faces were published in the local paper. For Larry, a young gay man at the forefront of the Kenyan LGBTIQ activism, it had taken courage to identify as a gay man in public. While he did so in the activist scene, he hadn't told his family. The publication of activists' identities was thus of great concern for many. The very same week, a Muslim cleric publicly demanded that the government arrest "the gays," leading to religious hostility towards homosexuality that has spiraled over the years. ${ }^{1}$ Such a public witch hunt was new to Kenya and marked the starting point of similar episodes in which religious leaders, particularly in the coastal areas along the Kilifi, Mombasa, and Kwale county lines, incited mob violence through anti-homosexuality rhetoric. As a result, several named gay people were threatened and attacked. ${ }^{1}$ Researchers have linked similar incidents of ${ }^{1}$ religious intolerance and criminalization of homosexuality to violence, stigma, blackmail, and extortion (Mbote et al., 2016; HRW, 2015; KHRC, 2012).

At the end of the World Social Forum, LGBTIQ activists and allies released a joint statement that outlined universally agreed-upon human rights principles of equality for all. The organizers thought it might be safer if a woman presented it, because, they presumed, lesbians pose less of a threat compared to men who have sex with men. Kasha, a lesbian from Uganda, read the statement at a concert held at Uhuru Park. The message did not resonate with many of those in attendance, and it caused an uproar among opposing members of the public soon after her declaration. With claims that homosexuality is un-African, those not in agreement accused her and the organizers of the $Q$-spot of continuing colonial ideas and of being paid by Western governments to advance the "homosexuality agenda" in Africa. Suggestive media reports were partly fueled by awareness of international donors' financial support and the presence of Western allies at

9 "We're here! We're queer!" is part of a popular chant at LGBTQI demonstrations and marches; the lines are sometimes followed by "health for all!" and most recently "\#repeal 162" or "love is human."

1 Galgalo Bocha, "Clerics Seek Harsher Laws for Gays," Daily"Nation, June 13, 2011.

1 https://ilga.org/world-social-forum-nairobi-2007 
the Q-spot tent. ${ }^{1}$ The reports connected the struggles of LGBTIQ Kenyans to the marriage equality debates taking place in several countries in Western Europe and North America.

The accusations and aggressive backlash impacted how LGBTIQ activists and their organisations related to each other and to the international NGOs. Some had to take a backseat and/or actively positioned themselves differently. For example, allies like LVCT took a backseat in favor of positioning GALCK to outside world. The MSM Program Coordinator at LVCT, a gay white male, kept his mentorship role but stepped out of the spotlight, while three local black queer activists became the face of the LGBTIQ activist scene to counter and minimalize the impact of the accusations and criticism. Eventually, a Kenyan lesbian woman replaced the leadership and long-term involvement of an openly gay white man as the head of the MSM program at LVCT.

While the backlash was real, the division between international queer/gender activism on the one hand, and local public health activism, on the other hand, is not. Instead, we argue, it is an intertwined and interdependent activist scene operating in a politicized national and international environment. Recognizing this ambiguous interdependency helps illuminate how current LGBTIQ activism is a microcosm of the power relations among the Kenyan state, international NGOs, and local grassroots activists.

\section{Ambiguously Interdependent: NGOization and LGBTIQ Activism}

Despite the upheaval that followed the Q-spot event, the Kenyan LGBTIQ activist scene grew expediently. A baseline survey (Karugu, 2011) indicates that there were 35 LGTBIQ groups in 2011, of which eight were MSM-oriented spin-offs of HIVIAIDS organizations. The funds held by these initiatives were minimal and ranged between 2,000 and 10,000 euros, and all except five were entirely supported by volunteers. As stated, these various initiatives represented very different constituencies with divergent interests, strategies, and long-term goals.

TEA, for example, emphasizes the need for medical access (hormones therapy, and psychological/psychiatric care) and legal recognition (change of names, identification documents) for trans people, while GALCK and NGLHRC increasingly adopted a human-rights approach premised on individual freedom (access to health, freedom of association) and gender-queer identities (equality and nondiscrimination on the basis of sexual orientation, gender identity). Rather than existing as independent initiatives, these groups very much operate within the same national and international field, and the daily connections, cooperation, and overlap of activists among multiple groups are readily observed. The ambiguous relations among this closely-knit yet conflicted niche activist scene primarily center on questions of resources, representation, and access (McCarthy \& Zald, 1977; Tarrow, 1998; Friedman \& McAdam, 1992).

1 Some of the transnational connections supporting GALCKS Q-spot included the International Lesbian and Gay Association (ILGA), the International Gay and Lesbian Human Rights Commission (IGHLRC), the South-South Dialogue, and the Dutch Development Agency Hivos. 
As LGBT groups sprang up throughout East Africa, so did donor support. In 2011, a baseline survey on LGBTI organizing Kenya indicated that most of the groups interviewed highlighted organizational development and a lack of functional finance management systems as key concerns (Karugu \& Mbaru, 2011). As organizations and donors expressed the need for capacity development, a lively discussion on what exactly that should entail followed. At the 2011 CFCS $^{1}$ conference, some voiced a desire to implement governance standards for LGBTIQ community-based organizations, arguing that in order to sustain their efforts, LGBTIQ organizations needed collective formalization. An NGO Quality Assurance Mechanism ${ }^{1}$ (QuAM), developed in Uganda, was presented as a mechanism that could enhance the credibility and effectiveness of $L G B T I Q$ and sex workers' groups. Others suggested instituting boards and general meetings as methods to formalize governance structures within the LGBTIQ organizations. Yet, while participants agreed to the need for accountability, they did not find that formalizing processes would be suitable because most LGBTIQ groups were not yet ready for that stage. With ongoing tensions around "NGOisation" and institutionalization of the various groups (Karugu \& Mbaru, 2011), two unresolved concerns that were brought forward were representation (who should be on the board of these local activist organisations) and strategic priorities (which approach and actions to push for). Despite valid concerns, all agreed accountability and some level of professionalization were necessary.

In response, Hivos a Dutch INGO and UHAlan indigenous LGBTIQ and sexworkers activist fund in East Africa, established the Jisort program, which is Kenyan slang for "sort yourself out." The program was launched in Kenya, Tanzania, and Uganda in 2012, and in Rwanda and Burundi in 2013. With a financial investment of more than half a million Euros from Hivos and UHAI, Jisort supported organizational development and interventions to strengthen the capacities of LGBTIQ and sex worker movements. Jisort was designed as a four-year program to increase the abilities of LGBTIQ and sex workers' groups, and translate their theories of change, advocacy goals, values, and desired impact into concrete action plans (Maina, 2013). These plans were meant to help organizations identify and engage with allies, mainly international ones; find resources; enhance activists' knowledge and skills; develop and implement effective strategies; and participate in and contribute to various platforms for change. Action plans also enabled them to participate in LGBTIQ networks and in other closely related initiatives, such as those concerned with women's rights, human rights, or HIV and AIDS prevention.

Mentoring sessions were set up to advise on project planning, report writing, financial management, and communication and advocacy strategy development. Most of the sessions were aimed at professionalizing Kenyan LGBTQI groups, which meant that each group formulated their objectives, aligning their practices with their stated visions, and translating them into concrete short- and long-term plans. However, as discussed elsewhere (Sutherland \& Klugman, 2013; Theron, McAllister \& Armisen, 2016), organizational priorities reflected what donors were willing to fund. Still, for some groups, these sponsored mentoring

1 The Third Regional Changing Faces Changing Spaces Conference, 3-6 May 2011, Kenya.

1 http://quamuganda.org/about-the-ngo-quality-assurance-mechanism-quam/what-is-quam/ QUAM is a selfassessment tool developed for NGOs by NGOs to enhance credibility and effectiveness. 
sessions were considered very productive. As a result, Nyanza, Rift Valley, and Western Kenya Network (NYARWEK) developed a strategic plan; ISHTAR MSM constituted a board to govern its implementation, and TEA set up accounting systems and trained its staff in bookkeeping.

At the same time, this donor-supported and donor-oriented process revived old tensions and sparked new concerns about the heavy emphasis on professionalization at the expense of group/movement dynamics and leadership, especially in cases of smaller groups that did not want to professionalize at all. In other instances, in-group tensions about strategic prioritizing emerged, such as when to engage the law, of which petitions 150 and 234 to decriminalize homosexuality in Kenya are striking examples. Dan, an LGBTIQ activist organisation leader in Kisumu, explained these petitions in a 2016 interview:

Now we have two petitions that have been merged and will be heard by the same bench. An individual filed the first case, petition 150, and although it directly touches on the unconstitutionality of sections 162-165, it is framed in an elite legal language, that many LGBTIQ community members struggle to grasp. Therefore, there was a need to engage the community and for them to be able to share their grievances as well and follow through the strategic litigation process - commonly referred to as the multi-tier approach as initially intended in a process that begun 2014, hence the second petition 234.

Filed in 2016, both petitions challenged the constitutionality of sections 162-165 of the Kenyan penal code and sought the decriminalization of the sex acts delineated in the code. Petition 150 was filed by Eric Gitari, a self-identified gay man and the director of National Gay and Lesbian Human Rights Commission (NGLHRC), but excluded other groups, including GALCK, Persons Marginalized and Aggrieved (PEMA) and Nyanza Rift Valley and Western Kenya Network (NYARWEK) from the process. This prompted GALCK, PEMA, NYARWEK, and activists from the sex worker-led group HOYMAS to file a more acceptable "community-led case" one month after petition 150. Petition 234, therefore, was premised on the notion of lived experiences of LGBTIQ Kenyans and sex workers as characterized by violence and discrimination they experienced. Prior to the filing of the petitions, the leadership of GALCK, PEMA, NYARWEK, and HOYMAS had, to some extent, involved grassroots groups, though most of the discussions took place in Nairobi, and amongst LGBTIQ leaders, donors, lawyers, and allies. Essy, a leader of a LGBTIQ organization stated:

We're calling it the "community petition" as discussed and agreed upon by LGBTIQ organizations and the constituents. ... We feel the community will own this petition because they can relate to the issues and people included in it; there is a lesbian, a sex worker, a trans person. Even more so, there is a representation outside of Nairobi, and it was also important to us that members of the LGBTIQ community were the petitioners and not presented as interested parties - that's huge! (Mombasa, 2016)

Deliberately, the leadership of LGBTIQ organizations kept the details surrounding the decriminalization petition out of the media, and the cases did not come to the public's attention until these were scheduled for a hearing. The hearing was a culmination of a process that began in 2014. Three LGBTIQ organizations (GALCK, NYARWEK, and NGLHRC) were tasked with drawing up the legal aspects of the decriminalization 
suit led by the NGLHRC, accompanied by a community-led communication strategy and a public engagement campaign led by GALCK and NYARWEK. In anticipation of the potential for violence against gender and sexual minorities, led by NYARWEK, safety and security measures would be established to deal with or address any threats. In the process of strategizing, NGLHRC felt the joint community consultation process was dragging and wanted to file the lawsuit before the Chief Justice Mutunga, a pro-LGBT human rights champion, left office.

Some transgender activists did not agree with this strategic decision and actively questioned the notions of sameness, equal representation, and connected struggles. Stella (seeking anonymity hence not her real name) explained:

If it were I, a transwoman trying to push a trans agenda down the throat of this sexual orientation gender identity and expression (SOGIE) fueled movement, I would not go far, and everyone would be resistant as they have sometimes been when it comes to trans issues. They take advantage of us, telling donors they [create] program[s] around transgender issues, yet [there are] no visible programs. So how come the gays can say they are speaking on behalf of the Kenyan LGBTIQ community, when all they are seeking is legal rights to have sex with one another? (Nairobi, 2017)

Bernstein (1997) contends that "identity" as it relates to social movements has at least three analytical dimensions: identify for empowerment, identity as goal and identity as a strategy (see also: Morris, 1992; Calhoun, 1994; Gamson, 1995). Organisations are likely to first, establish a shared collective identity necessary for mobilization, second, challenge or construct new forms of identity or deconstruct certain social categories, and third, deploy expressions of identity at the collective level as a political strategy. The Kenyan LGBT activist scene has adopted a structural way in forming coalitions, which are spaced geographically and bring together different LGBTIQ groups. As situated in the use of a particular language, representation, and resource opportunities, Kenyan LGBTIQ identity politics tend to challenge the notion of a united front and the need for a universal vision for social change based on sexual orientation, and gender identity and expression.

For example, GALCK lost membership of transgender affiliated groups such as TEA, due to the limited space to consider a variety of social change outcomes that differ from one LGBTIQ constituency to another.

Identity politics also manifest in the way different constituencies of LGBTIQ people identify, relate, or occupy social and political spaces. Jessy, who identifies as bisexual, for example, often feels excluded among fellow activists because bisexual activism remains invisible and deprioritized. Still, he regularly participates in LGBTQ meetings, and explains:

Sometimes you have to make a political statement by re-affirming your identity. And it does affect how you live your life afterward because you know you can't let go of that identity. If you do, you're going to let go of a struggle you've involved yourself with all along, and you don't want to be seen as abandoning the cause. (Nairobi, 2018) 
Jessy feels that his position as a bisexual man and a prominent LGBT activist is a constant process of negotiating power among different constituencies in the movement. He believes that claiming minority status is a strategic way to be able to claim rights and influence policy making. But he also has to deal with prejudices from within the movement because some perceive him, as a bisexual, as enjoying "the best of both worlds." Jessy asserts that these identity politics are a double-edged sword:

The struggles we are having right now, the internal group fights, the strategic litigation, they are all about identity. However, sometimes it is also very separate to your daily life. For example, I might be in a social setting where I do not need to play any power games; you do not need to gain any favors by showing how powerful you are compared to other gays or sex workers. But you still own those labels because you're in a social space, you want to be identified with particular people, and you don't want to be out of the club. You must be able to sit at a table with a group of people who feel they're very suspicious of you while you're one of them. But other times, it's also purely political for me to say I am bisexual-after all, there is a reason why the "B" is there in LGBT acronym. (Nairobi, 2018)

In court, LGBTIQ activists argue for laws that can only be applied by discriminating, by recognizing a person's gender, sexual identity, or sexual orientation. Jessy, like many, sees this as both problematic and necessary because the court and public need to understand that the violence and stigma experienced by sexual minorities stem from their perceived sexual practices:

So, I must take on an identity that is explicitly or exclusively defined based on my sexual practice, but at the same time, I want to tell you to have no business in my bedroom. I don't need to tell you what I do and how I make love. Not even whether I have sex or not. It is sometimes both, sometimes one of them. I don't think there is anyone who lives their identity as a political identity exclusively. (Nairobi, 2018)

Resources such as funding and training are tied to both the ascribed and chosen identities of Kenyan LGBTIQ activists in multiple ways. And these resources and identity politics, in turn, relate to access. As noted earlier, the move of HIVIAIDs care from hospital sites to stand-alone clinics created space for support groups and socializing for people who identify as LGBTIQ. This new access to mobilizing as an LGBT community, however, has not been equally shared, and it did not dissolve stigmatization against, or within, this emerging community. Openly gay men from Nairobi, for example, took a more prominent role in this community than did male or female sex workers in Nairobi, Kisumu, and Mombasa (Igonya, 2017).

Second, the occupation and class background of the activists largely determined who took the lead in activism. Activists with professional/regular day jobs, higher education, and public speaking experience were deemed more effective spokespersons and were more likely to know about and participate in facilitating projects such as Jisort. These intersectional class, gender, and sexuality differences (Crenshaw, 1990; Gordon, 2016; Moyer \& Igonya 2018) among activists thus created unequal access to local, national, and international advocacy platforms. 
Third, it cannot be emphasized enough that unequal access to targeted healthcare, representation in claimsmaking processes, and funding opportunities still persist in Kenya today amongst LGBTIQ groups. These are not merely individual voices of concern but represent broader tensions within the activist community, mostly between gay Nairobi activists who are perceived as elite and transgender activists and sex workers who perceive themselves as marginalized. These tensions spring from competition over resources, such as funding and mentoring sessions, but is continued in light of identity politics within the Kenyan LGBTIQ activist scene.

\section{Conclusion}

The debates surrounding petitions 150 and 234 flesh out a rift between Kenyan gay and lesbian activists, on the one hand, and transgender and intersect activists on the other. Where The National Gay and Lesbian Human Rights Commission aimed to register their NGO as a broad human rights initiative, transgender and intersex activists sought a clear distinction between gender and sexual orientation (what one does) and transgender and intersex (who one is). We pose that this is not only an ideological difference but reflects complicated relationships within the LGBTIQ activism scene in contemporary Kenya.

The disproportional prevalence of HIVIAIDS among MSM and sex workers in the late nineties saw a rise in NGOs and activist initiatives that advocated for and provided access to HIV counseling, treatment, and care. Clinics started by these health initiatives proved a site for activist mobilization, which signaled a shift in emphasis towards freedom, visibility, and a human rights approach. This did not, however, negate the need for access to HIV interventions and facilities and thus created an ambiguous but intertwined activist scene riddled with different strategies, priorities, and identity politics.

Approaching current LGBTIQ activism in Kenya as a niche activism scene enables an analysis that encompasses the historical, local, and specific development of NGOization of LGBTIQ activist groups and places the various activists' groups, in all their ambiguity, within the political context in which they operate. This foregrounds competition over resources, organizational interdependence, in-group marginalization, representation, and access to much needed medical care as well as access to platforms and (inter)national audiences.

Drawing on knowledge gained through professional expertise and academic-practitioner research, this paper foregrounds the effect of NGOization on LGBTIQ activism in Kenya. Because the urgent need for access to HIV treatment is intertwined with the need for LGBT emancipation using a human rights approach, not only in Kenya but everywhere, recognizing the complexity of a conflicted yet interdependent activist scene can inform practitioners and scholars in other locations. Furthermore, stepping away from reductionist identity politics and attending to the politicized context, including resources and critical questions of access, can help local activists position themselves to further their goal of inclusive social justice, which is, ultimately, not the same for everyone. 


\section{References}

Bernstein, M. (1997). Celebration and suppression: The strategic uses of identity by the lesbian and gay movement. American Journal of Sociology, 103(3): 531-65.

Boellstorff, T. (2011). But Do Not Identify as Gay: A proleptic genealogy of the MSM category. Cultural Anthropology 26(2): 287-312.

Bornstein, L. (2003). Management standards and development practice in the South African aid chain. Public Administrations and Development, 23: 393-404.

Calhoun, C. (Ed.) (1994). Social theory and the politics of identity. Cambridge, MA: Blackwell.

Crenshaw, K. (1990). Mapping the margins: Intersectionality, identity politics, and violence against women of color. Stanford Law Review, 43: 1241.

Currier, A. (2014). Arrested solidarity: Obstacles to intermovement support for LGBT rights in Malawi. Women's Studies Quarterly, 42(3/4): 146-163.

Elbers, W., \& Arts, B. (2011). Keeping body and soul together: Southern NGOs' strategic responses to donor constraints. International Review of Administrative Sciences, 77(4): 713-732.

Epprecht, M. (2012). Sexual minorities, human rights and public health strategies in Africa. African Affairs, 111(443): 223-243.

Friedman, D., \& McAdam, D. (1992): Collective identity and activism. In A. Morris \& C. McClurg Mueller (Eds.), Frontiers in social movement theory, 156-173. New Haven, CT: Yale University Press.

Gamson, J. (1995). Must identity movements self-destruct? A queer dilemma. Social Problems, 42(3): 390407.

Gordon, L. (2016). 'Intersectionality', socialist feminism and contemporary activism: Musings by a secondwave socialist feminist. Gender \& History, 28(2): 340-357.

Heyer, A. S., Mabuza, L. H., Couper, I. D., \& Ogunbanjo, G. A. (2010). Understanding participation in a hospital-based HIV support group in Limpopo Province, South Africa. South Africa Family Practice, 52(3): 234-239.

Igonya, E. K. (2017). My brother's keeper? Care, support and HIV support groups in Nairobi, Kenya. Amsterdam, Netherlands: Amsterdam Institute for Social Science Research (UVA-AISSR).

Karugu, N., \& Mbaru, M., (2011). Lived Realities, Imagined Futures: A Baseline of Lesbian, Gay, Bisexual, Transgender, and Intersex Organizing in Kenya. Baseline Survey Report. UHAI, Nairobi Kenya.

KHRC. (2011). The outlawed amongst us: A study of the LGBTI community's search for equality and nondiscrimination in Kenya. Nairobi: Kenya Human Rights Commission.

Lennox, C., \& Waites, M. (Eds.) (2013). Human rights, sexual orientation and gender identity in the Commonwealth: Struggles for decriminalization and change. London: School of Advanced Study, University of London.

Levitsky, S. (2007). Niche activism: Constructing a unified movement identity in a heterogeneous organizational field. Mobilisation: An International Quarterly, 12(3): 271-286.

Lorway, R., Thompson, L. H., Lazarus, L., du Plessis, E., Pasha, A., Mary, P. F., Khan, S., \& Reza-Paul, S. (2014). Going beyond the clinic: Confronting stigma and discrimination among men who have sex with men in Mysore through community-based participatory research. Critical Public Health, 24(1): 73-87. 
Kohl 6.1

Maina Ayiera, E. A. (2013). Ji-Sort Evaluation Report. Nairobi, Kenya.

Mbote, D. K., Sandfort, T. G. M., Waweru, E., \& Zapfel, A. (2016). Kenyan religious leaders' views on samesex sexuality and gender nonconformity: Religious freedom versus constitutional rights. Journal of Sex Research, 55: 630-641.

McCarthy, D., \& Zald, N. (1977). Resource mobilization and social movements: A partial theory. American Journal of Sociology, 82: 1212-1241.

Mohan, G. (2002). The disappointment of civil society: The politics of NGO intervention in northern Ghana. Political Geography, 21: 125-154.

Morgan, R., \& Wieringa, S., (2005). Tommy boys, lesbian men and ancestral wives: Female same sex practices in Africa. Sister Namibia, 17(3): 30.

Morris, A. D. (1992). Political consciousness and collective action. In A. D. Morris \& C. Mueller (Eds.) Frontiers of Social Movement Theory. New Haven, CT: Yale University Press.

Moyer, E., \& Igonya, E. (2018). Queering the evidence: Remaking homosexuality and HIV risk to 'end AIDS' in Kenya. Global Public Health, 13(8): 1007-1019.

Narayanaswamy, L. (2014). NGOs and feminisms in development: Interrogating the 'Southern Women's NGO'. Geography Compass, 8(8): 576-589. New York: Pantheon Books.

NASCOP. (2009). Kenya: HIV prevention response and modes of transmission analysis. Nairobi: National AIDS and STI Control Programme. Ministry of Health, Kenya.

NASCOP (2012). Programme data and MARPS size estimate consensus report. Nairobi: Ministry of Health, Kenya.

Nguyen, V. (2013). Counselling against HIV in Africa: a genealogy of confessional technologies. Culture, Health \& Sexuality: Sexuality, Intimacy and Counselling: Perspectives from Africa, 15(sup4): S440S452.

Nguyen, T. A., Oosterhoff, P., Ngoc, P., Wright, P., \& Hardon, A. (2009). Self-help groups can improve utilization of postnatal care by HIV-infected mothers. Journal of the Association of Nurses in AIDS Care, 20(2): 141-152.

Nyeck, S. N., \& Epprecht, M. (2013). Sexual diversity in Africa: Politics, theory, and citizenship (Vol. CEL version). Montréal, Quebec: MQUP.

Sanders, E., Jaffe, H., Musyoki, H., Muraguri, N. \& Graham, S. (2015). Kenyan MSM: No longer a hidden population. AIDS, 29: S195-S199.

Sandfort, T. G., \& Reddy, V. (2013). African same-sex sexualities and gender-diversity: An introduction. Culture, Health \& Sexuality, 15 (Suppl): 1-6.

Sharma, A. (2008). Logics of empowerment: Development, gender and governance in neoliberal India. Minneapolis: University of Minnesota Press.

Sutherland, C., \& Klugman, B. (2013). Finding common ground: a participatory approach to evaluation. Research Report. African Evaluation Journal, 1(1): e1-e10.

Tamale, S. (2011). African sexualities: A reader. Oxford: Pambazuka Press.

Tarrow, S. (1998). Power in movement: Social movements and contentious politics (2nd ed., Cambridge Studies in Comparative Politics). Cambridge: Cambridge University Press.

Teunis, N. (2001). Same-sex sexuality in Africa: A case study from Senegal. AIDS and Behavior, 5(2): 173182. 
Theron, L., McAllister, J., \& Armisen, M. (2016). Where do we go from here? A call for critical reflection on queer/LGBTIA+ activism in Africa. Pambazuka News.

Thoreson R., \& Cook, S. (Eds.) (2011). Nowhere to turn: Blackmail and extortion of LGBT people in SubSaharan Africa. New York: International Gay and Lesbian Human Rights Commission.

Thoreson, R. (2008). Somewhere over the Rainbow Nation: Gay, Lesbian and Bisexual Activism in South Africa. Journal of Southern African Studies, 34(3): 679-697.

Townsend, J.G., Porter, G., \& Mawdsley, E. (2004). Creating spaces of resistance: Development NGOs and their clients in Ghana, India and Mexico. Antipode, 36(5): 871-889.

Waites, M. (2009). Critique of 'sexual orientation' and 'gender identity' in human rights discourse: Global queer politics beyond the Yogyakarta Principles. Contemporary Politics, 15(1): 137-156.

Wilson, B. D. M., Neubauer, L. C., Park, A., Abuor, P. \& Harper, G. W. (2019). The sexual health needs the of sexual minority women in Western Kenya: An exploratory community assessment and public policy analysis. Global Public Health, 14(10): 1495-1508. 